\title{
Antioxidant and Anti-inflammatory Effects of Bletilla striata Reichenbach fil. Fractions as Cosmetic
}

\author{
Ji-Hun Yoon', Seong-Geun Park', Mi-Ji Lee', Jin-Young Park², Kyo-Seong Seo ${ }^{3}$, Kyung-Chul Woo ${ }^{4}$ \\ and Chang-Eon Lee ${ }^{1} *$
}

\author{
${ }^{1}$ Department of Cosmeceutical Science, Daegu Haany University, Gyeongsan 712-715, Korea \\ ${ }^{2}$ Skin science R\&D Center, Cosmelab Co. Ltd, Gyeongsan 712-210, Korea \\ ${ }^{3}$ Small and Medium Business Administration, Daegu 704-833, Korea \\ ${ }^{4}$ Korean Research institute for Skin science, Newlife Cosmetics Ltd, Gyeongsan 712-210, Korea
}

Received March 30, 2013 /Revised August 13, 2013 /Accepted September 10, 2013

\begin{abstract}
The antioxidant and anti-inflammatory effects of active ingredients in cosmetics are very important. The effects are closely related to the prevention of skin aging. Among medicinal plants, Bletilla striata Reichenbach fil. has well-known pharmacological activity. Extracted samples were prepared using sequential fractionation of ethyl acetate, butanol, and water. The antioxidant effect of the fractions was confirmed by DPPH and ABTS+ radical scavenging. Among the various fractions of B. striata Reichenbach fil., ethyl acetate was associated with a reduction in nitric oxide production, which was induced by LPS (lipopolysaccharide) treatment in a dose-dependent manner. In addition, the production of iNOS (inducible nitric oxide synthase) and COX-2 (cyclooxygenase-2), which are upstream regulators of nitric oxide production, was also inhibited. Thus, the ethyl acetate fraction of $B$. striata Reichenbach fil. appears to be a potential active ingredient for use in cosmetics.
\end{abstract}

Key words : Anti-oxidant, Induced-Nitric oxide synthase (iNOS), cyclooxygenase-2 (COX-2), fraction, Bletilla striata Reichenbach fil.

\section{서 론}

백급(Bletilla striata Reichenbach fil.)은 난초 과 자란 속에 속 하는 여러해살이 풀이다. 자란 속은 동아시아에 여러 종이 있 으며 우리나라에는 대암풀(백급)이 자라고 있다. 전남지방의 해남이나 진도 및 유달산에 많이 자생한다고 보고되어 있으며 산과 들, 계곡 등의 다습하고 양지쪽에 잘 자라며 다육질인 달걀형의 알뿌리에서 나온 5 6개의 잎이 서로 감싸면서 줄기 처럼 된다. 가을에 덩이줄기를 캐서 물에 씻어 증기에 쪄서 햇빛에 말려 한약재로 사용되고 있으며 약리작용으로는 지혈 작용, 위 및 십이지장궤양 치료, 옹종, 화상, 손발이 트는데 사용한다고 예부터 알려져 왔으며 연구되어있다[1]. 백급의 성 분에 대한 연구로서 bibenzyl과 dihydrophenanthrene, bleti$\operatorname{lol~A,~B,~Cㄱㅏ~ㅂㅗㄱㅗㄷㅚㅇㅓ~ㅇㅣㅆㄷㅏ[13,~15].~ㅂㅐㄱㄱㅡㅂㅇㅢ~ㅍㅣㅂㅜㅇㅏㄴㅈㅓㅇㅅㅓㅇㄱㅘ~ㄷㅗㄱ~}$ 성에 관하여 안정하다는 연구가 되어있다[19]. 그리고 백급의 효능으로서 백급 메탄올추출물이 멜라닌 형성을 억제한다는

\footnotetext{
*Corresponding author

Tel : +82--53-819-1594, Fax : +82-53-819-1594

E-mail : lce1351@dhu.ac.kr

This is an Open-Access article distributed under the terms of the Creative Commons Attribution Non-Commercial License (http://creativecommons.org/licenses/by-nc/3.0) which permits unrestricted non-commercial use, distribution, and reproduction in any medium, provided the original work is properly cited.
}

\section{보고가 되어있다[18].}

생체 내의 free radical은 반응성이 강하고 여러 생체물질과 쉽게 화학반응을 일으켜 세포에 손상 및 염증을 유발하며, 고 혈압, 동맥경화, 심부전, 류마티스 관절염, 알레르기, 암, 노화 등에 영향을 준다. 인체는 산화촉진물질(pro-oxidant)과 산화 억제물질(antioxidant)이 균형을 이루고 있으나 여러 가지 요 인들에 의하여 이런 균형상태가 불균형을 이루게 되고 산화촉 진 쪽으로 기울게 되면, 산화적 스트레스(oxidative stress)가 유발되어 잠재적인 세포손상 및 병리적 질환을 일으키게 된 다.[8] 이러한 산화적 스트레스의 직접적 원인이 되는 활성 산 소 종(reactive oxygen species, ROS)은 불안정하고 반응성이 높아 여러 생체물질과 쉽게 반응하고, 체내 고분자들을 공격 하여 세포와 조직에 비가역적인 손상을 일으키거나 돌연변이, 세포독성 및 발암 등을 초래하게 된다[12]. - $\mathrm{NO}, \mathrm{HNO}_{2}$, $\mathrm{ONOO}^{-}$등과 같은 활성 질소 종(reactive nitrogen species, $\mathrm{RNS})$ 은 염증 반응 시 대식세포 호중구 및 다른 면역 세포들의 면역반응으로 인해 다량 생성되며, 이때 ROS도 같이 생성된 다[14]. 염증 반응의 조절은 대단히 복잡한 것으로 알려져 있는 데, 이는 생체 내 복구체계의 증강 및 손상을 감소시키기 위한 것으로 알려져 있다. 그러나 반복되는 조직의 손상이나 재생 에 의해 염증반응이 지속되면 염증관련 세포에서 ROS와 RNS 가 과다 생성되고 그 결과로 영구적인 유전적의 변형이 야기 된다[8]. 이처럼 ROS와 RNS는 생체 내 여러 가지 세포의 작용 을 조절하는 염증반응과 깊이 관련되어 있다. 염증 과정 중 
에서 많은 양의 염증유도 cytokine (pro-inflammatory cytokine), nitric oxide (NO) 그리고 prostaglandin E2 (PEG2)가 inducible nitric oxide synthase (NO)와 cyclooxygenanse-2 (COX-2)에 의해 생성되며, 포유세포에서 NO는 neuronal $\mathrm{NOS}$ (nNOS), endothelial NOS (eNOS) 그리고 iNOS 세가지 형태의 NOS에 의해 합성된다. $\mathrm{nNOS}$ 와 $\mathrm{eNOS}$ 는 세포 내에 항상 존재하지만, iNOS는 interferon- $\gamma$, lipopolysaccharide (LPS) 그리고 다양한 염증유도 cytokine에 노출되는 경우에만 발현된다[2, 13].

일반적으로 염증 반응뿐만 아니라 발암, 심장병, 노화 등의 문제를 억제하기 위해 항산화제를 사용하며, 특히 경제성과 우수한 항 산화력으로 인한 BHT (butylated hydroxy tolune), BHA (butylated hydroxy anisole), PG (propyl gallate) 등의 항산화제가 널리 사용되고 있다. 그러나 이 같은 합성 항산화 제를 장기간 섭취 시 간, 폐, 건강, 순환계 등에 심각한 독성을 일으키는 것으로 알려져 있어, 독성과 부작용이 적은 허브나 약용식물 등을 이용한 항산화제 및 항 아토피치료제의 개발이 요구된다. 따라서 본 연구에서는 현재 피부에 대한 약리작용 에 대한 연구가 부족한 백급 분획물의 항 산화 및 항 염증 활성을 검증한 후 우수한 분획물이 항 노화, 피부염증 개선 화장품소재로서의 가능성을 검증하고자 한다.

\section{재료 및 방법}

\section{시료 제조}

본 연구에 사용한 백급은 다년생 풀인 대암풀의 덩이줄기부 분을 말린 것을 (주)옴니허브에서 구입하여 사용하였다. 음건되 어 있는 백급을 $70 \%$ 메탄올에 추출하였다. 이후 감압 농축하 여 동결건조를 한 건조된 분체를 분획 재료로 사용하였다. 시 료의 분획은 Fig. 1 과 같은 순서로 분획하였다. 백급 $70 \%$ 메탄 올추출물을 다음과 같은 용매인 에 틸아세테이트(Ethyl acetate), 부탄올(Butanol), 물(Water)로 분획하였다. 분획물은 에

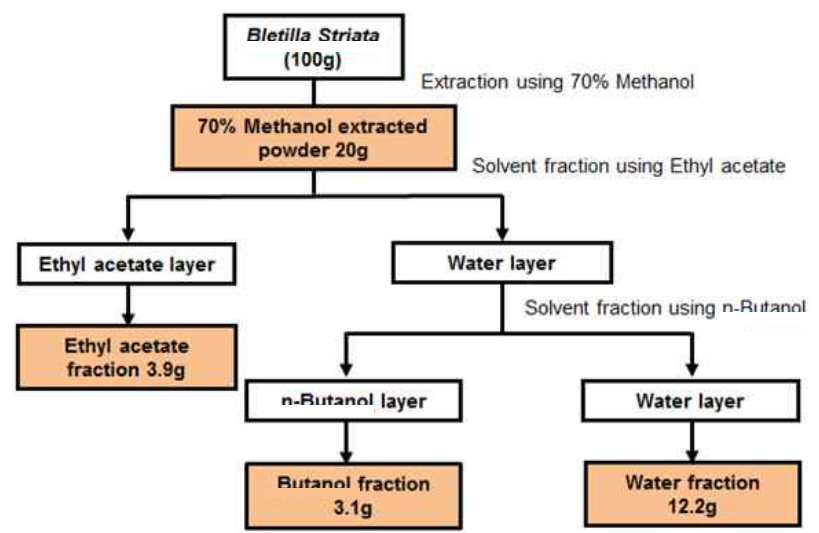

Fig. 1. Procedure for fraction of Methanol-extracts from $B$. striatá Reichenbach fil.
틸아세테이트 층에서 $3.9 \mathrm{~g}$, 부탄올 층에서 $3.1 \mathrm{~g}$, 물 층에서 $12.2 \mathrm{~g}$ 을 얻었으며, 분획물의 수율은 각각 $19.5 \%, 15.5 \%, 61 \%$ 이다. 분획을 통해 얻은 모든 시료는 초저온냉장고 $\left(-70^{\circ} \mathrm{C}\right)$ 에 보관하면서 본 실험의 시료로 사용하였다.

시약

항산화 효과 실험에 사용된 시약인 1,1-Diphenyl-2-picrylhydrazyl (DPPH), 2,2'-Azino-bis(3-ethylbenzthiazoline-6sulphonic acid), ascorbic acid, 3-[4,5-dimethylthiazol-2-yl]2,5-diphenyl-tetrazoliumbromide (MTT), lipopolysaccharide (LPS), 등은 Sigma Chemical Co. (St. Louis, MO, USA)에서 구입하여 사용하였다. 세포 주는 macrophage 세포인 Raw 264.7을 한국 세포 주 은행(KCLB, Korea)에서 구입하여 사용 하였다. DMEM high glucose, fetal bovine serum (FBS), penicillin/streptomycin, trypsin-EDTA solution 등은 PAA Lab. (PAA, Pasching, Austria)에서 구입하여 사용하였으며, bovine serum albumin (BSA) 등은 Bio basic Inc. (Markham, Ontario, Canada)에서 구입하여 사용하였으며, protein assay reagent 등은 Bio-rad Laboratories, Inc. (Hercules, CA, USA) 에서 구입하여 사용하였으며, COX-2, B-actin 등은 Santa Cruz biotechnology, inc. (Santa Cruz, CA, USA)에서 구입하여 사 용하였으며, iNOS primary antibody, iNOS secondary antibody는 BD Transduction Laboratories (Sanjose, CA, USA)에 서 구입하여 사용하였다.

\section{항산화 효과 측정}

\section{전자공여능 효과 측정}

전자공여능(electron donating ability, $\mathrm{EDA}$ )은 Blois의 방법 [3]을 변형하여 측정하였다. 각 시료용액 $100 \mathrm{ul}$ 에 $0.2 \mathrm{mM}$ 의 2,2-diphenyl-1-picryl hydrazyl (DPPH) $0.05 \mathrm{ml}$ 넣고 상온에 서 30 분간 방치한 다음 $515 \mathrm{~nm}$ 에서 흡광도를 측정하였다. 전 자공여능은 시료용액의 첨가 군과 무 첨가 군의 흡광도 감소 율로 나타내었다.

\section{ABTS radical 소거능 측정}

ABTS radical을 이용한 항 산화력 측정은 Roberta 방법[11] 에 의하여 측정하였다. $7 \mathrm{mM}$ 2,2-azino-bis (3-ethylbenzthiazoline- 6-sulphonic acid)와 $2.4 \mathrm{mM}$ potassium persulfate를 혼합하여 실온인 암소에서 24 시간 동안 방치하여 $\mathrm{ABTS}+{ }^{-}$을 형성시킨 후 Ethanol로 희석 하여 $\mathrm{ABTS}^{*}{ }^{*} 0.1 \mathrm{ml}$ 에 시료 0.1 $\mathrm{ml}$ 를 가하여 7분 동안 방치한 후 $734 \mathrm{~nm}$ 에서 흡광도를 측정하 였다.

\section{항염증 효과 측정 \\ 세포배양}

본 실험에 사용한 세포(Raw 264.7)는 한국세포주은행(KCLB, Korea)에서 구입하여 사용하였다. 세포 배양은 DMEM high 
glucose 배지에 FBS 10\%와 penicillin/streptomycin 1\%를 첨 가하여 사용하였으며, $37^{\circ} \mathrm{C}, 5 \% \mathrm{CO}_{2}$ incubator에 적응시켜 배 양하였다.

\section{MTT assay에 의한 세포 생존율 측정}

세포 생존율 측정은 Carmichael의 방법[5]에 따라 측정하였 다. Raw 264.7를 96 well plate에 hemocytometer를 이용해 $0.6 \sim 8 \times 10^{3}$ cells/well이 되게 분주하여 24시간 동안 배양하고, 12 시간 후 시료를 농도 별로 조제하여 첨가한 후 $37^{\circ} \mathrm{C}, 5 \%$ $\mathrm{CO}_{2}$ incubator에서 24시간 동안 배양하였다. 대조 군은 시료 와 동량의 시료용매를 첨가하여 동일한 조건으로 배양하였다. 여기에 $5 \mathrm{mg} / \mathrm{ml}$ 농도로 제조한 MTT용액 $0.02 \mathrm{ml}$ 을 첨가하여 4 시간 배양한 후 배양액을 제거하고 각 well당 DMSO : etha$\mathrm{nol}(1: 1) 0.1 \mathrm{ml}$ 를 가하여 실온에서 30 분간 반응시킨 후 550 $\mathrm{nm}$ 에서 흡광도를 측정하였다. 세포 생존율 측정은 시료용액 의 첨가 군과 무 첨가 군의 흡광도 감소율로 나타내었다.

\section{Nitric Oxide 소거능 측정}

Nitric Oxide 소거능 측정은 Gray와 Dugan의 방법[6]으로 측정하였다. 농도 별로 제조한 각 시료용액 $0.05 \mathrm{ml}$ 에 $20 \mathrm{mM}$ phosphate buffer $0.05 \mathrm{ml}$ 과 $20 \mathrm{mM}$ phosphate buffer에 용해 한 sodium nitroferricyanide (III) dihydrate $0.05 \mathrm{ml}$ 을 첨가하 였다. 이 반응용액을 $37^{\circ} \mathrm{C}$ 에서 150 분간 반응한 다음, griess reagent $0.1 \mathrm{ml}$ 을 첨가하였다. 실온에서 150 분간 방치하고 542 $\mathrm{nm}$ 에서 흡광도를 측정하여 잔존하는 아질산염 양을 측정하 였다. Nitrite 소거능은 시료용액의 첨가 군과 무첨가 군의 흡 광도 감소율로 나타내었다.

\section{Western blot분석을 통한 iNOS, COX-2 단백질의 발현 측정}

항염증 관련 단백질을 측정하기 위하여 Raw 264.7 세포를 FBS $10 \%$ 와 phenicillin/streptomycin $1 \%$ 를 첨가한 DMEM high glucose 배지에 $100 \mathrm{~mm}$ tissue culture dish $2 \times 10^{6}$ 개의 cell/well이 되도록 분주하고 24 시간 동안 배양하였다. Confluence가 $80 \%$ 일 때, serum free MEM $9 \mathrm{ml}$ 로 12시간 이상 적응시킨 후 lipopolysaccharide (LPS) $1 \mu \mathrm{gg} / \mathrm{ml}$ 을 control 군 을 뺀 모든 dish에 넣어서 자극시켰다. 1시간 후에 시료를 농도 별로 $1 \mathrm{ml}$ 처리하여 24시간 후 배지를 제거하고 $\mathrm{PBS}$ 로 3회 세척 후 각 dish에서 세포를 수확하여 cell lysis buffer를 첨가 한 후 단백질을 Bradford법[4]을 통하여 정량하였다. 시료를 SDS-polyacrylamide gel에 전기영동 후 nitrocellulose membrane으로 transfer하였다[11]. Primary antibody를 항 염증 관 련 단백질인 iNOS를 $1 / 1,000$ 로 희석하였고, COX-2를 $1 / 3,000$ 으로 희석하여 membrane과 함께 over night 한 다음 TBST로 10 분간 5 회 세척 후 secondary antibody $1 / 1,000$ 으로 희석하 여 membrane과 함께 실온에서 1 시간 넣어 두었다. 이에 TBST 로 10분간 5회 세척 후 X-ray film에 감광하여 ECL (enhanced chemiluminescence) Kit를 사용하여 만든 발색시약으로 band
를 확인하였다.

\section{결과 및 고찰}

\section{항산화 효과 측정}

\section{전자공여능 효과 측정}

백급 메탄올 추출물의 물 분획 층, 부탄올 분획 층 그리고 에틸아세테이트 분획층 중 항 산화 활성이 가장 높은 분획 층을 확인하기 위하여 전자공여능 효과를 측정한 결과 Fig. 2 와 같다. 대조 군으로 천연 항산화제인 Vitamin $\mathrm{C}$ 를 사용하 였다. 백급 메탄올 추출물의 물 분획 층의 경우 $10 \mu \mathrm{g} / \mathrm{ml}$ 에서 $4.6 \%, 50 \mu \mathrm{g} / \mathrm{ml}$ 에서는 $8.3 \%, 100 \mu \mathrm{g} / \mathrm{ml}$ 에서는 $10.7 \%, 500 \mu \mathrm{g} /$ $\mathrm{ml}$ 에서 $17.2 \%$ 그리고 $1,000 \mu \mathrm{g} / \mathrm{ml}$ 에서는 $25.1 \%$ 로 매우 낮은 활성을 나타내었다. 반면 에틸아세테이트 분획 층의 경우 $11.6 \%, 14.5 \%, 39.6 \%, 80.4 \%, 89.3 \%$ 로 Vitamin C에 비해 저 농도에서는 낮은 활성을 보였지만 $500 \mu \mathrm{gg} / \mathrm{ml}$ 부터 $80 \%$ 이상으 로 Vitamin C $(88.7 \%)$ 와 유사한 높은 활성을 나타내었다. 따라 서 물, 부탄올, 에틸아세테이트 분획 층 중 에틸아세테이트 분획 층이 가장 우수한 전자공여능 효과를 나타내는 것으로 확인하였다. 따라서 백급 메탄올 추출물의 에틸아세테이트 분 획 층에 항산화 효과가 우수한 물질이 다량 존재하는 것으로 사료된다.

\section{ABTS radical 소거능 측정}

백급 메탄올 추출물의 물 분획 층, 부탄올 분획 층 그리고 에틸아세테이트 분획층 중 항 산화 활성이 가장 높은 분획 층을 확인하기 위하여 ABTS+free radical 소거활성 측정법을 이용하여 측정한 결과 Fig. 3과 같다. 대조군으로 천연 항산화 제인 Vitamin C를 사용하였다. 백급 메탄올 추출물의 물 분획 층의 경우 $10 \mu \mathrm{gg} / \mathrm{ml}$ 에서 1.5\%, $50 \mu \mathrm{g} / \mathrm{ml}$ 에서는 2.3\%, $100 \mu \mathrm{g} /$

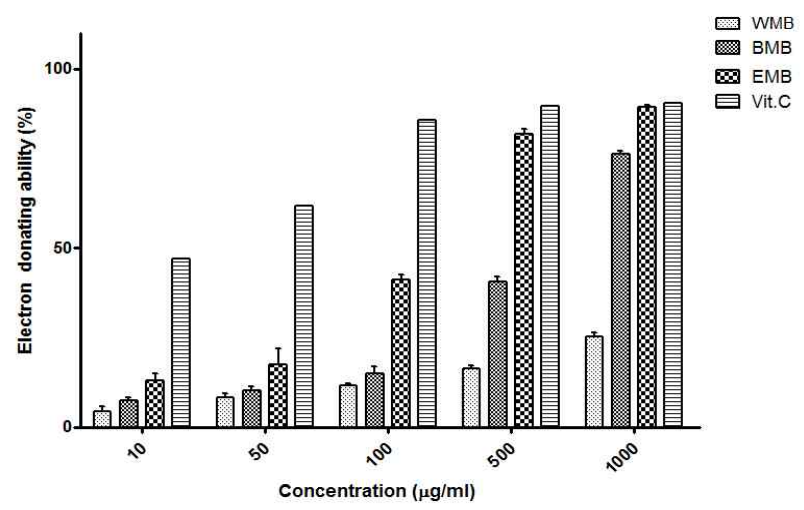

Fig. 2. Electron donating ability of fractions of Bletilla striata Reichenbach fil. fraction. Results are means \pm S.D. of triplicate data. (WMB: Water fraction of Methanol extracts from Bletilla striata Reichenbach fil., BMB: Butanol fraction of Methanol extracts from Bletilla striata Reichenbach fil., EMB: Ethyl acetate fraction of Methanol extracts from Bletilla striata Reichenbach fil., Vit.C: Ascorbic acid). 


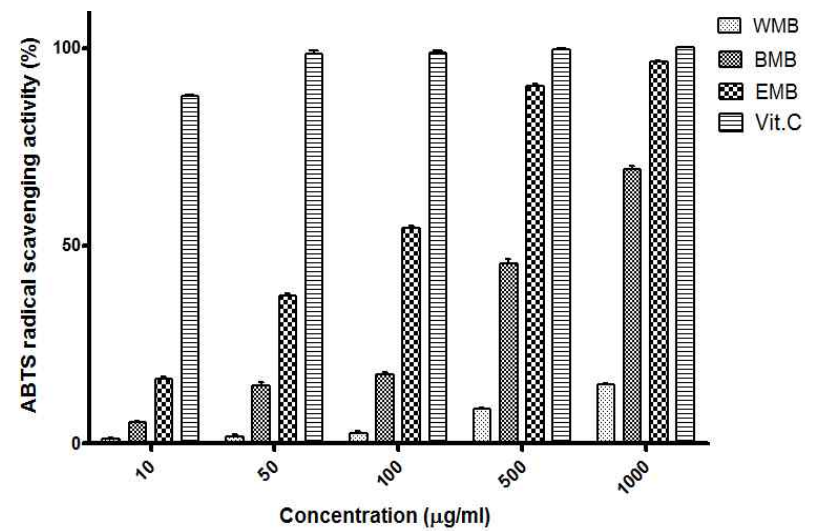

Fig. 3. ABTS radical cation scavenging activity of Bletilla striatá Reichenbach fil. fraction. Results are means \pm S.D. of triplicate data. (WMB: Water fraction of Methanol extracts from Bletilla striata Reichenbach fil., BMB: Butanol fraction of Methanol extracts from Bletilla striata Reichenbach fil., EMB: Ethyl acetate fraction of Methanol extracts from Bletilla striata Reichenbach fil., Vit.C: Ascorbic acid)

$\mathrm{ml}$ 에서는 $3.5 \%, 500 \mu \mathrm{g} / \mathrm{ml}$ 에서 $9.4 \%$ 그리고 $1,000 \mu \mathrm{g} / \mathrm{ml}$ 에서 는 $15.3 \%$ 로 매우 낮은 활성을 나타내었다. 반면 에 틸아세테이 트 분획 층의 경우 $17.2 \%, 38.2 \%, 55.4 \%, 90.3 \%, 95.8 \%$ 로 Vitamin C에 비해 저 농도에서는 낮은 활성을 보였지만 500 $\mu \mathrm{g} / \mathrm{ml}$ 부터 $80 \%$ 이상으로 Vitamin C (99.1\%)와 유사한 높은 활성을 나타내었다. 따라서 물, 부탄올, 에틸아세테이트 분획 층 중 에틸아세테이트 분획 층이 가장 우수한 ABTS+ free radical 소거효과를 나타내는 것으로 확인하였으며 백급 메탄올 추출물의 에틸아세테이트 분획 층에 항산화 효과가 우수한 물질이 다량 존재하는 것으로 사료된다.

\section{항 염증 효과 측정}

Mouse macrophage cell (RAW 264.7)의 세포생존율 $\mathrm{EMB}$ 에 대한 세포독성을 확인하기 위하여 RAW 264.7 cell 에 $\mathrm{EMB}$ 을 처리하고 24시간 이후 $\mathrm{MTT}$ assay를 측정한 결과, Fig. 4 와 같다. $\mathrm{EMB}$ 을 처리하지 않은 세포 $(100 \%)$ 와 비교하였 을 때 $\mathrm{EMB}$ 를 $50,100,250 \mu \mathrm{g} / \mathrm{ml}$ 처리한 세포에서 각각 $99.4 \%$, $98.7 \%, 96.1 \%$ 로 세포생존율을 나타내었으며 $85 \%$ 이하의 세포 생존율의 감소는 나타나지 않았다. 따라서 $\mathrm{EMB}$ 의 50, 100, 250 $\mu \mathrm{g} / \mathrm{ml}$ 농도에서 모두 세포독성은 나타나지 않은 것으로 확인 하였다. 이후 RAW 264.7 cell을 대상으로 하는 항 염증 관련 실험에서는 $\mathrm{EMB}$ 농도를 위와 같이 $50,100,250 \mu \mathrm{g} / \mathrm{ml}$ 농도를 실험에 사용하였다.

\section{Nitric Oxide 소거능 측정}

Nitric Oxide $(\mathrm{NO})$ 는 면역기능에 관여하지만, 과량 존재할 경우 인체에 유해한 영향을 미치게 되어 세포손상 및 염증 반응으로 이어지게 된다고 보고되어 있다[9]. 또한 superoxide 음이온 $\left(\mathrm{O}_{2}\right)$ 과 쉽게 반응하여 매우 반응성이 높고 독성이 강한

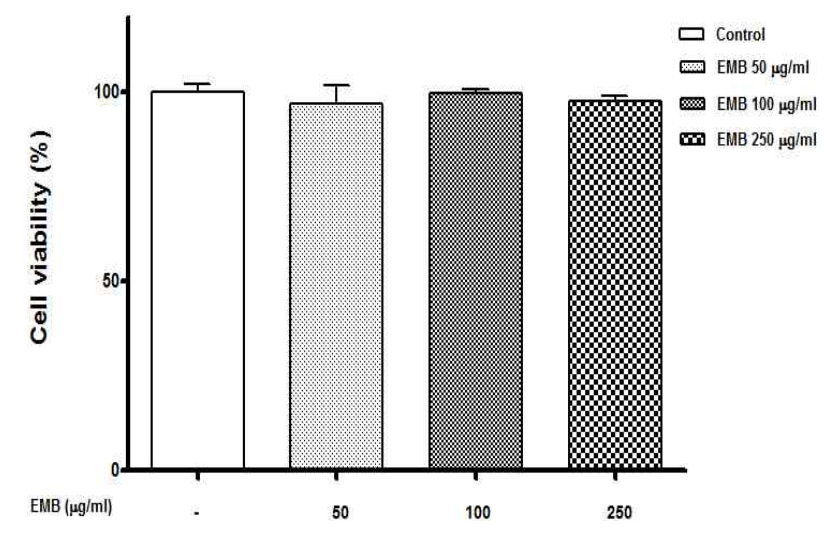

Fig. 4. Cell viability rate of EMB on RAW 264.7 cell. Cells were treated with $\operatorname{EMB}(50,100,250 \mu \mathrm{g} / \mathrm{ml})$ and the cells were further incubated for $24 \mathrm{hr}$. Cell viability was measured by MTT assay. Results are means \pm S.D. of triplicate data. (EMB: Ethyl acetate fraction of Methanol extracts from Bletilla striata Reichenbach fil.)

산화제인 peroxynitrite를 생성한다. 본 실험에서는 $\mathrm{EMB}$ 이 염 증을 유발하는 $\mathrm{NO}$ 을 소거하는 활성을 확인하기 위하여 LPS 로 $\mathrm{NO}$ 의 발생을 유도 한 후, 이후 $\mathrm{EMB}$ 을 처리하여 $\mathrm{NO}$ 의 감소하는 양을 다음과 같이 Fig. 5에 나타내었다. LPS를 처리 하지 않은 cell에서는 $\mathrm{NO}$ 의 양이 $0.5 \mu \mathrm{M} / \mathrm{ml}$ 으로 측정되었고, LPS를 처리한 cell은 $\mathrm{NO}$ 의 양이 $21.1 \mu \mathrm{M} / \mathrm{ml}$ 으로 높아지는 것을 확인하였다. 이후 $\mathrm{EMB}$ 을 $50,100,250 \mu \mathrm{g} / \mathrm{ml}$ 처리한 cell 에서는 각각 $19.23,12.36,5.34 \mu \mathrm{M} / \mathrm{ml}$ 으로 농도 의존적으로 $\mathrm{NO}$ 의 양이 감소하는 것을 확인하였다. 따라서 $\mathrm{EMB}$ 의 우수한 아질산염 소거 능으로 보아 $\mathrm{EMB}$ 에 항염증과 관련된 활성물질

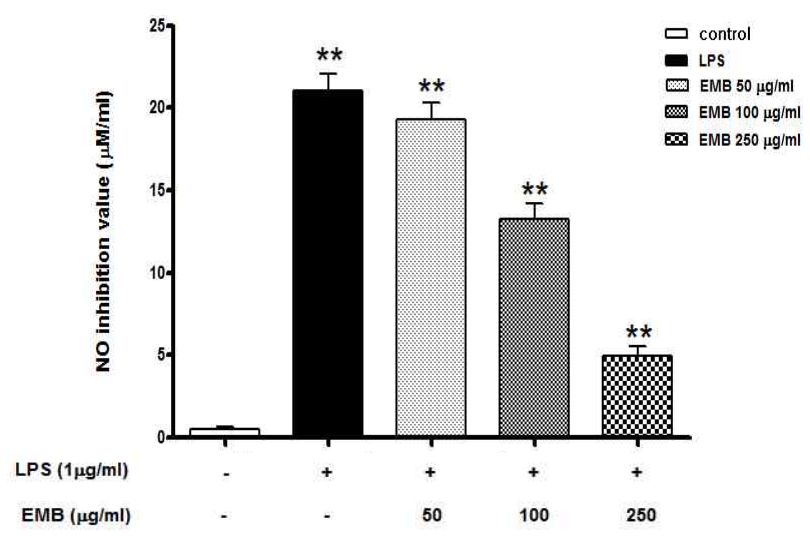

Fig. 5. The effects of EMB on NO production in RAW 264.7 cells. Raw 264.7 cells were cultured with LPS $(1 \mu \mathrm{g} / \mathrm{ml})$ in the presence or absence of EMB $(50,100,250 \mu \mathrm{g} / \mathrm{ml})$ for $24 \mathrm{hr}$ to determine the level of NO. NO production was determined in culture supernatant by Griess reagent. "**" indicates $p<0.05$, "***" indicates $p<0.001$ and "NS" indicates not statistically significant with respect to untreated control. (EMB: Ethyl acetate fraction of Methanol extracts from Bletilla striata Reichenbach fil.) 


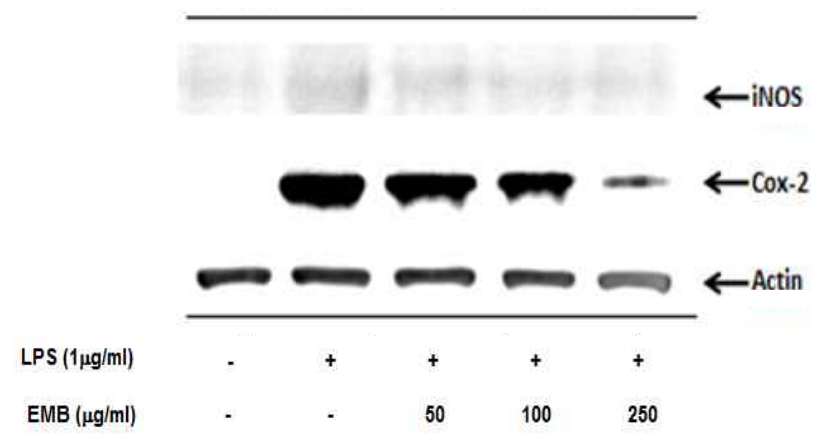

Fig. 6. The effects of EMB on iNOS and COX-2 protein expression in RAW 264.7 cells. The RAW 264.7 cells $\left(2 \times 10^{6}\right.$ cells $/ \mathrm{ml}$ ) were incubated $24 \mathrm{hr}$ and the cells were stimulated with lipopolysaccharide $(1 \mathrm{\mu g} / \mathrm{ml})$ for $1 \mathrm{hr}$. And then treated with $\operatorname{EMB}(50,100,250 \mu \mathrm{g} / \mathrm{ml})$ for $24 \mathrm{hr}$. Expression of $\beta$-actin is shown as loading control (Control: Untreated LPS, EMB: Ethyl acetate fraction of Methanol extracts from Bletilla striata Reichenbach fil., iNOS: Inducible Nitric oxide synthase, COX-2: Cyclooxygenase-2)

이 다량 존재하는 것으로 사료된다.

Western blotting을 통한 iNOS, COX-2 단백질의 발현 측정 체내 염증과정에서는 과량의 nitric oxide (NO) 및 prostaglandin E2 (PEG2) 등의 염증인자는 유도형 NO synthase (iNOS)와 cyclooxygenase (COX-2)에 의해 생성된다고 알려져 있다[6]. 따라서 세포에서 LPS와 같은 독소 및 특수한 자극제 들에 노출될 경우 생성되는 $\mathrm{iNOS}$ 와 COX-2 단백질을 LPS로 유도 시킨 후, $\mathrm{EMB}$ 을 처리하여 그 발현량의 감소를 western blot을 통해 확인하였다. Fig. 6과 같이 LSP를 처리하지 않은 cell에 비해 LPS를 처리하여 자극한 cell의 iNOS와 COX-2의 발현량이 높아진 것을 확인 할 수 있다. 반면 LPS를 처리하고 $\mathrm{EMB}$ 을 처리한 cell에서는 그 감소 양이 농도의존적으로 감소 하는 것으로 나타났다. 따라서 LPS에 의해 증가된 iNOS와 $\mathrm{COX}-2$ 의 발현량을 $\mathrm{EMB}$ 이 감소시킴으로 인해 염증반응과 관 련된 $\mathrm{NO}$ 의 생성량을 감소시키고 따라서 항 염증 효과를 가진 것으로 사료된다.

\section{감사의 글}

본 연구는 중소기업청 지원사업(과제번호: 0046975, C0035644) 의 지원을 받아 수행되었으며 이에 감사 드립니다.

\section{References}

1. Ahn, D. K. 1998. Illustrated Book of Korean Medicinal Herbs, pp. 42, Kyo-Hank Publishing, Seoul, Korea.

2. Bae, E. A., Han, M. J. and Kim, D. H. 2001. In vitro antihelicobacter pylori activity of irisolidone isolated from the flowers and rhizomes of Pueraria thunbergiana. Planta Med
67, 161-163.

3. Blois, M. S. 1958. Antioxidant determination by the use of a stable free radical. Nature 26, 1199-1120.

4. Bradford, M. M. 1976. A rapid and sensitive method for the quantitation of microgram quantities of protein utilizing the principle of protein dye binding. Anal Biochem 72, 248-254

5. Carmichael, J., DeGraff, W. G., Gazdar, A. F., Minna, J. D. and Mitchell, J. B. 1987. Evaluation of a tetrazolium based semiautomated colorimetric assay: assessment of chemosensitivity testing. Cancer Res 47, 936-942.

6. Choi, S. Y., Chung, M. J. and Sung, N. J. 2008. Studies on the antioxidative ability of methanol and extracts from Orostachys japonicas A. Berger according to harvest time. Korean J Food Nutr 21, 157-164.

7. Gray, J. I. and Dugan, L. R. 1975. Inhibition of N-nitrosamine formation in model food systems. J Food Sci 40, 981-984.

8. Jiang, W.-Y. 2005. Therapeutic wisdom in traditional Chinese medicine: a perspective from modern science. Trends Pharmacol Sci 26, 558-563.

9. Kubo, M., Sasaki, M., Namba, K., Naruto, S. and Nishimura, H. 1975. Isolation of a new isoflavone from Chinese Pueraria flowers. Chem Pharm Bull 23, 2449-2451.

10. Lim, S. S., Shin, K. H., Bang, H. S., Kim, Y. P., Jung, S. H., Kim, Y. J. and Ohuchi, K. 2002. Effect of the essential oil from the flowers of Magnolia sieboldii on the lipopolysaccharide- induced production of nitric oxide and prostaglandin E2 by rat peritoneal macrophages. Planta Med 68, 459-462.

11. Towbin, J., Staehlin, T. and Gordon, J. 1979. Electrophoretic transfer of proteins from polyacylamide gels to nitrocellulose sheets: procedure and some applications, Proc Natl Acad Sci USA 76, 4350-4354.

12. Re, R., Pellegrini, N., Proteggente, A., Pannala, A., Yang, M. and Rice-Evans, C. 1999. Antioxidant activity applying an improved ABTS radical cation decolorization assay. Free Radic Biol Med 26, 1231-1237.

13. Shuzo, T., Masae, Y. and Keiko, I. 1983. Antimicrobial agents from Bletilla striata. Phytochemistry 22, 1011-1015.

14. Xue, T. H. and Roy, R. 2003. Studying traditional Chinese medicine. Science 300, 740-741.

15. Yamaki, M., Bai, L., Kato, T., Inoue, K. and Takagi, S. 1993. Three dihydrophenanthropyrans from Bletilla striata. Phytochemistry 32, 427-430.

16. Yeung, D. K. Y., Leung, S. W. S., Xu, Y. C., Vanhoutte, P. M. and Man, R. Y. K. 2006. Puerarin, an isoflavonoid derived from Radix Pueraria, potentiates endothelium-independent relaxation via the cyclic AMP pathway in porcine coronary artery. Euro J Pharmacol 552, 105-111.

17. Ye, J., Zhang, X., Dai, W., Yan, S., Huang, H., Liang, X., Li, Y. and Zhang, W. 2009. Chemical fingerprinting of Liuwei Dihuang Pill and simultaneous determination of its major bioactive constituents by HPLC coupled with multiple detections of DAD, ELSD and ESI-MS. J Pharm Biomed Anal 49, 638-645. 
18. Yoon, H. J., Yoon, J. W., Yoon, S. W., Ko, W. S. and Woo, W. H. 2003. Inhibitory effect on melanogenesis of Rhizoma Bletillae. J Oriental Med Ophthamol Otolaryngol Dermatol 16, 100-111.
19. Zhang, W., Ma, S., Gu, G., Shi, J. and Zhao, B. 2003. Studies on the toxicological assessment on skin safety of polysaccharide gum of Bletilla striata (THUNB.) REICHB. Chinese Wild Plant Res 22, 59-61.

초록 : 백급(Bletilla striata Reichenbach fil.) 분획물의 항산화, 항염증 효과와 화장품소재로서의 연구

윤지훈 ${ }^{1} \cdot$ 박성근 $^{1} \cdot$ 이미지 ${ }^{1} \cdot$ 박진영 $^{2} \cdot$ 서교성 ${ }^{3} \cdot$ 우경철 $^{4} \cdot$ 이창언 ${ }^{1} \star$

( ${ }^{1}$ 대구한의대학교 화장품약리학과, ${ }^{2}$ (주코스메랩, ${ }^{3}$ 대구경북지방중소기업청, ${ }^{4}$ (주신생활피부과학연구소)

항산화, 항염증 효과는 화장품 소재에서 중요한 요소이다. 항산화, 항염증은 피부노화 예방과 밀접한 관련이 있다. 백급은 이전부터 약리활성이 뛰어난 것으로 알려져 왔다. 실험재료는 백급의 에틸아세테이트, 부탄올, 물 분획물을 사용하였다. 항산화 효과는 DPPH, ABTS+ radical scavenging 실험으로 확인하였다. 다양한 분획물 중, 백급의 에틸아세테이트 분획물이 LPS에 유도된 nitric oxide의 생성을 농도 의존적으로 감소시키는 것을 증 명하였다. 게다가, nitric oxide 생성의 상위 기작인 iNOS, COX-2 단백질 발현도 저해하였다. 우리는 백급 분획 물의 항산화, 항염증 효과가 항 노화 및 피부염증 개선 화장품 소재로서의 가능성을 기대한다. 